\title{
ПОСЛОВИЦЫ О ДИКИХ ЖИВОТНЫХ В СЛАВЯНСКИХ ЯЗЫКАХ
}

\section{Proverbs on Wild Animals in Slavic Languages}

Keywords: folklore, proverbs, kinship of languages, Slavic languages, general laws of thought

Contact: МГПУ; kristina.mir22@gmail.com

Фольклор - это художественная творческая деятельность народа, создаваемые народом и бытующие в народных массах произведения словесного творчества, музыка, танец, архитектура, изобразительное и декоративно-прикладное искусство. Зародившись за долго до нашей эры, в эпоху первобытно общинного строя, народное творчество стало основой всей мировой культурой. С возникновением профессионального «высокого» искусства фольклор не утратил своего значения, образуя особый культурный пласт, впитавший в себя многовековой народный опыт.

Бесценной частью народного творчества являются пословицы. Пословицами называют короткие, организованные ритмически, устойчивое в речи образные изречения народа, обладающие способностью к полисемичному употреблению с использованием аналогии.

«За пословицами стоит многовековая мудрость народов, опыт целых поколений. Пословицы хранят знание о мире и о человеке в этом мире, являются наряду с другими формами культуры, "автобиографией народа", "зеркалом культуры", что делает интересным и плодотворным их изучение в рамках когнитивной лингвистики, в плане реконструкции на их основе пословичного представления о мире - пословичной картины мира. Примечательно, что слово "картина" в связи с теми представлениями и образами, которые возникают в сознании при чтении пословиц, употребил В. И. Даль. А изобразил пословичную картину мира П. Брейгель, написав полотно "Нидерландские пословицы", которое состоит из отдельных картинок - пословиц. Подобно этому произведению пословичная картина, реконструируемая лингвистом, слагается из множества 
пословичных единиц. Понятие "языковая картина мира" является чрезвычайно популярным в современном языке, отдельные фрагменты языковой картины мира анализируются на различном языковом материале, пословичная картина мира отдельный фрагмент, часть языковой картины мира» (Лиске 2016: 8).

Пословицы известны как фольклорный жанр столько же, сколько известен сам язык. Иными словами, время появления пословиц как жанра ученым не известно. Они бытовали в устном народном творчестве, позже появились отдельные письменные фиксации в средневековой литературе: летописях, повестях, сказаниях. В частности, пословицы включены автором в текст величайшего произведения древней восточнославянской литературы «Слове о полку Игореве». В средние века в Европе были составлены первые рукописные собрания пословиц, где для разъяснения метафорического смыла нередко использовались иллюстрации. До наших дней дошли десятки собраний пословиц, которые были созданы, главным образом, в XIII-XIV вв. В Московской Руси еще до широкого распространения печати собрания пословиц были созданы рукописным способом, в XVII и XVIII вв. было опубликовано первое печатное собрание.

Мудрость, меткость, яркость пословиц позволили им стать нравственными ориентирами классической русской литературы. Пословица Береги честь смолоду начинает в качестве эпиграфа «Капитанскую дочку» А. С. Пушкина. Пословица Неча на зеркало пенять, коли рожа крива предпослана «Ревизору» Н. В. Гоголя. Широко использовали пословицы и другие писатели. Лингвисты и фольклористы нашли в романе «Война и мир» Л. Н. Толстого десятки пословиц и поговорок, в «Тихом Доне» М. А. Шолохова удалось обнаружить сотни паремий.

Несмотря на краткость, пословицы наполнены глубоким смыслом. В них отражены самые важные стороны народной жизни: религиозные взгляды, общественный и бытовой уклад, знания о жизни, природе, представления о морали, семейных ценностях, дружбе. «Пословица недаром молвится» - гласит народная мудрость.

Изучая пословицы разных народов, можно отметить, что, несмотря на этносемантическую окраску, связанную с уникальностью языковой картины мира каждого языка, вариативность текстов малых фольклорных жанров, они обладают множеством общих семантических моделей и культурных мотивов. Особенно это касается народов, живущих по соседству, в сходных природных и социальных условиях. «Пословицы и поговорки отражают богатый исторический опыт народа, представления, связанные с трудовой деятельностью, бытом и культурой 
людей. Они обогащают речь, делая ее эмоциональной, образной и выразительной. Пословицы разных народов часто передают схожие жизненные ситуации, которые, однако, в разных языках получают свое образное и ритмическое представление, но с общим поучительным смыслом» (Мартизанова 2017: 111).

В настоящей статье ставится цель проанализировать в чешском, польском и русском языках пословицы, в которых используются образы диких животных.

Человек и животный мир всегда были неразрывно связаны. Звери могли быть опасными врагами и верными друзьями, их приручали и на них охотились, с ними были связаны многие культовые и мистические представления. Наблюдая за животными, люди наделяли их определенными качествами. Если говорить об образах зверей, чаще всего использовавшихся в фольклоре России, Польши и Чехии, то медведь - представлялся неуклюжим, опасным, медлительным, глупым, лиса - хитрой, умной, расчетливой, коварной, заяц - трусливым, проворным, быстрым, хвастливым, волк - злым, голодным, страшным.

Живя в тесном соседстве с дикими зверями, человек издавна проводил аналогии между собой и животным миром. «Животные могли составлять социальную иерархию, а многие люди связывали свое происхождение с животными. Поэтому многие пословицы и поговорки включают в себя сравнение человека с животными. Человек часто прибегал к сравнению с тем, что было ему ближе всего, стремясь охарактеризовать свое состояние, поведение, чувства, внешность» (Юсупова 2017: 194).

Рассмотрим в русском пословном переводе некоторые наиболее часто употребляемые пословицы из русского, польского и чешского языков. Материал собран путем перевода русских пословиц на польский и чешский языки с использованием искусственного интеллекта «DeepL»- ведущего машинного переводчика современности, - который осуществляет не пословный перевод, а подбор синонимической паремии, и обратного буквального (пословного) перевода на русский язык для анализа семантической модели паремии. Разумеется, такой способ отбора материала суживает возможный круг изучаемых единиц, что плохо. Но любая успешная лингвистическая концепция в своей основе содержит идею редукционизма: нельзя изучать весь язык вообще, можно изучать систематически обобранные языковые единицы. Положительными сторонами такого способа отбора материала являются: во-первых, верифицируемость материала с помощью новейших прогрессивных технологий, во-вторых, актуальность отобранного материала в рамках современной цифровой 
цивилизации, в-третьих, общедоступность и общепонятность материала, т. е. высокая степень его визуализации.

Таблица № 1: Сравнение значения фразеологизмов

\begin{tabular}{|c|c|c|}
\hline Русский язык & Чешский язык & Польский язык \\
\hline $\begin{array}{l}\text { Не дели шкуру не убитого } \\
\text { медведя }\end{array}$ & $\begin{array}{l}\text { Не дели шкуру, пока она } \\
\text { на медведе }\end{array}$ & $\begin{array}{l}\text { Не дели шкуру } \\
\text { неубитого медведя }\end{array}$ \\
\hline $\begin{array}{l}\text { Убить двух зайщев одним } \\
\text { ударом }\end{array}$ & $\begin{array}{l}\text { Убить двух мух одним } \\
\text { ударом }\end{array}$ & $\begin{array}{l}\text { Испечь два печенья на } \\
\text { одном огне }\end{array}$ \\
\hline $\begin{array}{l}\text { Работа не волк, в лес не } \\
\text { убежит }\end{array}$ & & $\begin{array}{l}\text { Работа не медведь, } \\
\text { можно и завтра } \\
\text { посмотреть }\end{array}$ \\
\hline $\begin{array}{l}\text { С волками жить, по- } \\
\text { волчьи выть }\end{array}$ & $\begin{array}{l}\text { С воронами жить, по- } \\
\text { вороньи каркать }\end{array}$ & \\
\hline $\begin{array}{l}\text { И волки сblmbl, и овц̧ьл } \\
\text { цุельь }\end{array}$ & & $\begin{array}{l}\text { Волк поел и коза иеела } \\
\text { осталась }\end{array}$ \\
\hline $\begin{array}{l}\text { Лукава лисица, да в } \\
\text { капкан попадет }\end{array}$ & $\begin{array}{l}\text { Таскал волк, потащуили и } \\
\text { волка }\end{array}$ & \\
\hline $\begin{array}{l}\text { Любить, как собака } \\
\text { палку }\end{array}$ & & $\begin{array}{l}\text { Любить, как лису в } \\
\text { курятнике }\end{array}$ \\
\hline $\begin{array}{l}\text { Пуганая ворона куста } \\
\text { боится }\end{array}$ & $\begin{array}{l}\text { Битому псу только } \\
\text { покажи лозу }\end{array}$ & \\
\hline $\begin{array}{l}\text { Лучше синица в руках, } \\
\text { чем журавль в небе }\end{array}$ & $\begin{array}{l}\text { Лучше воробей в кулаке, } \\
\text { чем голубь на крыше }\end{array}$ & \\
\hline $\begin{array}{l}\text { Всяк кулик свое болото } \\
\text { хвалит }\end{array}$ & $\begin{array}{l}\text { Каждая лиса свой хвост } \\
\text { хвалит }\end{array}$ & $\begin{array}{l}\text { Каждая лиса } \\
\text { (трясогузка) свой } \\
\text { хвост хвалит }\end{array}$ \\
\hline $\begin{array}{l}\text { Из пуши по воробьям не } \\
\text { стреляют }\end{array}$ & $\begin{array}{l}\text { Если собрался убить } \\
\text { муху, не бери пушку }\end{array}$ & \\
\hline $\begin{array}{l}\text { Дали орехов белке, когда } \\
\text { зубов не стало }\end{array}$ & & $\begin{array}{l}\text { Когда есть хлеб - нет } \\
\text { зубов, когда есть зубыл, } \\
\text { то нет хлеба }\end{array}$ \\
\hline
\end{tabular}

Из таблицы № 1 видно, что часть пословиц полностью совпадает, а часть несет ту же смысловую нагрузку при использовании образов других животных, или обходясь без них. Среди причин этой схожести можно выделить несколько основных:

1) развитие из одного источника;

2) этническое и языковое родство народов; 
3) возникновение на почве общих закономерностей социального развития, сходства законов мышления, общих законов метафоризации;

4) культурное взаимодействие народов, заимствования, обусловленные хозяйственными и культурными контактами.

Русская пословица Не дели шкуру неубитого медведя имеет весьма близкие соответствия в польском и чешском языке, что говорит о развитии из одного источника.

Русская пословица Убить двух зайцев одним ударом имеет более близкое соответствие в чешском языке (Убить двух мух одним ударом), свидетельствующее об отдаленном общем источнике, и менее близкое в польском, но построенное по той же модели «достичь двух результатов одним усилием» (Испечь два печенья на одном огне) с переносным значением 'найти способ рационализации своих действий, сильно повышающий эффективность'. Однако в польском языке зооним в этой пословице вообще не используется, значит речь может идти не об общем происхождении, а об общих закономерностях языка и социального развития.

Что касается поговорки Работа не волк, в лес не убежит, то в польском синониме использован зооним медведь (Работа не медведь, можно и завтра nосмотреть), что указывает на возможность общего с русской поговоркой источника, но весьма отдаленного, так что зооним есть в двух языках, но к какомто из них успел замениться.

Пословица С волками жить, по волчьи выть имеет соответствие в чешском языке с заменой зоонима на ворону (С воронами жить, по-вороньи каркать), что, на наш взгляд, свидетельствует об отдаленном родстве.

Поговорка И волки cblmbl, и овц̧ь ц̧ельы, включающая два зоонима, имеет один из них совпадающим в русском и чешском, а второй весьма близким: домашнее животное, копытное, разводится ради шерсти и молока. Все это говорит скорее об этническом и языковом родстве народов, чем о создании паремии по модели.

Паремия Лукава лисица, да в капкан попадет имеет в чешском синоним, где отличается и зооним, и модель, хотя прослеживается сходство метафор и вторичной семантики (Таскал волк, потащили и волка). Здесь речь может идти о возникновении поговорки на основе общих закономерностей социального развития: все крестьяне негативно относились к хищникам и зоонимная метафора, 
связанная с этими опасными животными, характеризует человека с отрицательной стороны, если используется в связи с его номинацией.

Выражение Любить, как собака палку является в русском языке скорее не поговоркой, а свободной метафорой. Наверное, именно поэтому польское соответствие весьма далеко не только по составу (не тот зооним) и по структуре, но и по метафорическому значению (Любить, как лису в курятнике). Т. е. между выражениями нет ни видимого родства, ни иных связей.

Пословица Пуганая ворона куста боится имеет в чешском языке семантически соответствующее выражение, где не только иной зооним, но и существенно изменена структура: появляется фигура деятеля (Битому nсy только покажи лозу). Однако метафорический смыл весьма схож, «субъект, испытавший вредоносное воздействие, склонен неоправданно ожидать такого воздействия вновь». Здесь речь идет о проявлении в метафоре общих законов человеческого мышления.

Русская поговорка Всяк кулик свое болото хвалит в польском имеет соответствие Всякая трясогузка хвалит свой хвост, где мы видим два упоминания птиц и общую модель с одинаковым по значению глаголом. Но не все так просто. В польском изначально там было слово лиса, причем в форме, пришедшей из чешского языка Každá liška svi̊j ocas chválí, со временем ставшей непонятной полякам. Зато в польском языке слово «трясогузка» оказалось весьма созвучным этому непонятному звуковому комплексу. Произошла народная этимологизация, в результате которой в польской поговорке животное заменили на птицу, и произошло случайное сближение с русской поговоркой. Поэтому в нашей таблице приведен перевод со словом «лиса». «Kiedy rzeczownik liszka w znaczeniu 'samica lisa' wyszedł z użycia, stało się jasne, że ludzie przestaną z czasem rozumieć jego sens i (...) zaczną "majstrować" przy powiedzeniu Każda liszka swój ogon chwali. Tak się stało. Wkrótce włączyli do niego nazwę (...) pliszka. Było to o tyle łatwiejsze, że po pierwsze formy liszka i pliszka mają podobne brzmienie (różnią się tylko jedną głoską i literą p), a po drugie pliszka to ptak o długim ogonku (czarnym z białymi brzegami), którym teoretycznie także może się chwalić» (Malinowski 2014: 1). Процитированное рассуждение объясняет, как в поговорках случайным образом может произойти замена зоонима по созвучию, причем это может не только приводить к расхождению поговорок в разных языках, но и к случайному же схождению.

Русская поговорка Из пуши по воробьям не стреляют имеет в чешском структурно и семантически весьма близкое соответствие, с другим зоонимом, 
называющим, однако, также летающее существо (Если собрался убить муху, не бери пушку). Такая близость позволяет говорить о возможном общем источнике и, соответственно, о древности этой поговорки, что возможно, учитывая, что славяне познакомились с пушками не позднее XIV века, но могли сталкиваться с ними и ранее.

Малоупотребительная русская поговорка Дали орехов белке, когда зубов унее не стало не находит западнославянских соответствий с зоонимом. Возможная по сближению поговорка не схожа ни структурно, ни метафорически. По всей видимости, здесь вообще не идет речь ни о родстве, ни о сходстве мышления или социального развития. Об этом же свидетельствует и малоупотребительность русской пословицы: скорее всего это новая метафора.

Лингвистам уже давно известно, что «у народов, находящихся в близком родстве, больше пословиц, имеющих буквальное сходство, чем у народов из разных языковых семей; а у соседних народов, связанных многовековыми контактами, больше буквально совпадающих изречений, чем у народов, не имевших непосредственного общения. И, конечно же, у народов, равно имеющих классово дифференцированное общество, будет больше сходных пословиц, чем у какого-нибудь отсталого племени, не знающего имущественного неравенства. Однако и у народов, не состоящих в родстве, не имеющих и не имевших общения друг с другом и находящихся на разных ступенях общественного развития, тоже встречаются одинаковые по смыслу пословицы» (Бичер 2014: 4). Это во многом объясняется тем, что «пословицы и поговорки представляют собой обобщение многовекового жизненного опыта народа, содержат эмоционально экспрессивную оценку поступков человека, событий, явлений. Поэтому они не сочиняются, а появление их как бы вынуждается силою обстоятельств, как крик или возглас, невольно сорвавшийся с души; это целые изречения, сбитые в один ком, в одно междометие» (Бичер 2014: 4).

Таким образом, можно сделать вывод, что несмотря на национальные особенности и вариативность, многие пословицы имеют схожий смысл. Сравнение пословиц разных народов показывает, как много общего имеют эти народы, способствует взаимопониманию и сближению людей.

Особенно хотелось бы подчеркнуть значение использования пословиц в педагогической практике. Изучение пословиц разных народов, несомненно будет способствовать воспитанию патриотизма, пробуждению интереса к культуре других стран, осознанию общности народных идеалов и ценностей, а также станет еще одной мотивацией к изучению иностранных языков. «Изучая 
пословицы и поговорки, мы изучаем культуру родной страны и страны изучаемого языка, начинаем осознавать себя частичкой одного большого и богатого культурного целого» (Бикчинтаева 2019: 104).

Сравнительный анализ пословиц русского, польского и чешского языков, содержащих зоонимы диких животных подтверждает предположение, что в этих языках существуют пословицы разной степени родства. В одних используются одинаковые зоонимы, в других - разные, но схожие, в третьих несхожие, и, наконец, есть случаи, где родство вообще не наблюдается. С точки зрения структурно-семантической сходство также может быть более или менее близким. Если родственные связи поговорок не просматриваются, но есть общность структуры и метафоры - можно видеть причину сходства в общих законах мышления, если же нет даже общности структуры, но есть сходство метафорического осмысления мира, причиной этого можно видеть общность социального развития.

\section{Summary}

Proverbs are short, organized rhythmically, steady in speech figurative sayings of the people. The aim of this article is to analyze proverbs in Czech, Polish and Russian that use images of wild animals. Comparative analysis of proverbs of Russian, Polish and Czech language containing zoonims of wild animals confirms the assumption that in these languages there are proverbs of different degree of kinship. Some use the same zoonims, others use different but similar ones, others use different proverbs, and finally, there are cases where kinship is not observed at all.

\section{Литература}

Бикчинтаева, Н. С. Отражение культуры турецкого народа в пословицах и поговорках. Via Scientiarum - Дорога знаний. 2019 (1), с. 99-104.

Бичер, О. Пословицы и поговорки с компонентом зоонимом в системе языка и лингвострановедческого знания. Universum: филология и искусствоведение. 2014 (18/6), с. 4.

Лиске, Н. В. Сравнительный анализ английских и русских пословиц и поговорок. In: Лиске, Н. В. (ed.) Филологические науки в России и за рубежом. СанктПетербург, 2016, с. 7-13. Режим доступа: https://moluch.ru/conf/phil/ archive/233/11356/ (2020-04-26). 
Мартизанова, X. 3. Пословицы и поговорки как отражение национальной культуры. Вестник Ингушского НИИ гуманитарных наук им. Ч. Э. Ахриева. 2017 (2), с. 109-111.

Юсупова, Л. Г., Кузьмина, О. Д. Анималистические паремиологические единицы с обозначениями диких животных в русском и немецком языках. Филологические науки. Вопросы теории и практики. 2017 (3), с. 194.

Malinowski, M. Co oznacza słowo liszka w powiedzeniu „,Każda liszka swój ogon chwali”. 2014. Режим доступа: https://obcyjezykpolski.pl/co-oznacza-slowoliszka-w-powiedzeniu-kazda-liszka-swoj-ogon-chwali/ (2020-04-26). 